\title{
DECADAL-SCALE VEGETATION DYNAMICS ABOVE THE ALPINE TREELINE, MOUNT RUFUS, TASMANIA
}

\author{
by Violet Harrison-Day, Bryan Annandale, Jayne Balmer and Jamie B. Kirkpatrick
}

(with four text-figures, four plates and three tables)

\begin{abstract}
Harrison-Day, V., Annandale, B., Balmer, J. \& Kirkpatrick, J.B. 2016 (15:xii) Decadal-scale vegetation dynamics above the alpine treeline, Mount Rufus, Tasmania.Papers and Proceedings of the Royal Society of Tasmania 150(2): 9-18. https://doi.org/10.26749/rstpp.150.2.9 ISSN 0080-4703. Geography and Spatial Sciences, School of Land and Food, University of Tasmania, Private Bag 78, GPO, Hobart, Tasmania 7001, Australia (VH, BA, JB, JBK*); Department of Primary Industries, Parks, Water, and Environment, GPO Box 44 Hobart, Tasmania 7001, Australia (JB).

*Author for correspondence. Email: j.kirkpatrick@utas.edu.au
\end{abstract}

\begin{abstract}
Alpine areas by definition have summer temperatures too cool to support trees. Concerns have been raised that trees may invade these distinctive habitats where global climate change results in an increase in summer temperatures beyond the threshold limiting tree growth. In 2016, we investigated changes in the treeline and vegetation immediately above it by resampling quadrats and rephotographing from the set points established in the Alpine Treeline Ecotone Monitoring Program on Mount Rufus, Tasmania, in 2006. Within the study area, the only species with the potential to reach a tree height $>3 \mathrm{~m}$ is Eucalyptus coccifera Hook.f. The height, density, basal diameter and diameter at breast height were recorded for all E. coccifera within the study area, together with an estimate of percentage cover of each vascular plant species. No change was found in the location of the treeline over the 10-year period, although E. coccifera height and density above the treeline did increase. The vegetation on the north-facing slope shifted to a composition more closely related to the forest below the treeline, while on the south-facing slope forest species reduced in abundance and the vegetation became more dominated by alpine species. Historical aerial photographs suggest that there has been a minor and inconsistent establishment of $E$. coccifera plants at higher altitudes since 1953. The area was burned by bushfire in 1965, making it difficult to separate the effects of putative climate change and recovery after the fire event on vegetation changes, although data from Lake St Clair suggest a local constancy of mean growing season temperatures and rainfall. Key Words: climate change, fire, subalpine forest, tree growth, tree mortality, Eucalyptus coccifera.
\end{abstract}

\section{INTRODUCTION}

Climate change is likely to have long-term effects on alpine ecosystems (Settele et al. 2014, Williams et al. 2015). The alpine zone, which is characterised by the absence of trees, is located between the alpine treeline and the line of permanent snow and ice. In Tasmania it is also characterised by a rich floristic diversity in which up to $70 \%$ of vascular plant species on particular mountains are endemic to Tasmania (Kirkpatrick 1982). The alpine treeline is defined by Paulsen \& Körner (2014) as the maximum line of elevation that connects groups of trees growing to a height of $3 \mathrm{~m}$ or more. It is distinct from the forest line (timberline), which is the mean maximum line of elevation at which trees form continuous cover (Paulsen \& Körner 2014). The alpine treeline forms where temperatures become too low to support tree growth. In Tasmania, trees are often excluded for other environmental reasons, making it difficult to locate the climatic treeline (Kirkpatrick 1982). The position of alpine treelines around the world has been modelled by Paulsen $\&$ Körner (2014) as a minimum growing season length of 94 days with all days exceeding a mean air temperature of $0.9^{\circ} \mathrm{C}$ and a mean air temperature of $6.4^{\circ} \mathrm{C}$ over the season. In Tasmania, Green \& Stein (2015) found that a mean growing season air temperature of $5.85^{\circ} \mathrm{C}$ predicted the area mapped as alpine by Kirkpatrick (1983). However, this mapped area includes treeless vegetation below the alpine treeline (Kirkpatrick 1983).

Increases in the elevation of alpine treelines are likely to affect alpine ecosystems (Harsch et al. 2009, Greenwood
\& Jump 2014, Hagedorn et al. 2014). The conical nature of many mountains with alpine ecosystems may result in the exponential shrinking of available habitat for alpine species as climates warm (Settele et al. 2014). Alpine treelines which are diffuse have advanced more than those of abrupt form (Harsch et al. 2009), although many alpine treelines have not changed in location, despite changes in climate (Harsch et al. 2009). In Australia, the biota of the alpine zone is thought to be particularly susceptible to climate change. Alpine and treeless subalpine areas occupy less than $0.15 \%$ of total land area (Costin $e t$ al. 1979), with areas above the alpine treeline constituting only $0.016 \%$ (Green \& Stein 2015). Alpine ecosystems occur within narrow altitudinal ranges, and are without a nival zone to provide potential refugia (Williams et al. 2015, Pickering et al. 2008). Species which are present at only the highest alpine elevation and in high alpine environments, such as snow patches, may be increasingly threatened, with some species and environments already having been assessed as being "endangered" according to IUCN Red List criteria (Pickering et al. 2008, Williams et al. 2015, Parry et al. 2016). In some alpine areas, such as the Snowy Mountains, greater local endemism is found at higher elevations, so increasing temperatures and decreasing snow cover may pose an extinction risk (Pickering et al. 2008). Increasing fire frequency and intensity caused by climatic change is also likely to threaten some Tasmanian species (Kirkpatrick \& Bridle 2013).

In the Snowy Mountains, alpine species could be at risk of extinction due to lack of refugia and encroachment 
by lower-elevation shrubs, herbs and introduced weeds (Pickering et al. 2008). Snow patches have declined, potentially threatening their specialised plant communities (Green \& Pickering 2009), and changes in snowmelt patterns have been found to affect vegetation growth, with implications for the future composition of plant communities (Venn et al. 2011). Venn et al. (2012) found that mean species richness has increased on the Snowy Mountain summits. Vegetation compositional changes have varied between higher- and lower-elevation summits (Venn et al. 2014) and between burned and unburned sites under experimental warming conditions (Camac et al. 2015). In Tasmania, there are no published data on recent vegetation change at and immediately above the alpine treeline, temporal studies having concentrated on recovery from fire (e.g., Kirkpatrick \& Dickinson 1984, Kirkpatrick et al. 2010), responses to grazing (e.g., Bridle et al. 2001, Kirkpatrick \& Bridle 2016) and mire and fjaeldmark dynamics (Gibson \& Kirkpatrick 1992, Kirkpatrick et al. 2002a).

Tasmanian alpine areas differ from those of mainland Australia in their maritime climate, which has led to differing patterns of precipitation, duration of snow cover, species composition and marsupial grazing, and in their histories of fire (Kirkpatrick \& Bridle 2013). While mainland alpine areas have vegetation which is able to recover swiftly from burning (Williams et al. 2008), Tasmanian alpine areas have a less extensive history of burning, and a higher incidence of fire-sensitive species, leading to long-term changes when burned rather than swift recovery (Kirkpatrick \& Bridle 2013).

Eucalyptus coccifera Hook.f., the Snow Peppermint, is endemic to Tasmania where it forms the alpine treeline on most eastern and central mountains (Williams \& Potts 1996). It intergrades with E. nitida Hook.f., which replaces it on quartzite mountains (Shaw et al. 1984). At lower elevations $E$. coccifera typically forms a tall, straight, single-stemmed tree up to $40 \mathrm{~m}$ in height. Tree height and leaf size decline with elevation, while glaucousness and lignotuber development increase. It is often of mallee form at the treeline (Pyrke \& Kirkpatrick 1994). The aboveground parts of the plant are usually killed by fire, the tree resprouting from the basal lignotuber. As with other eucalypts, seed is stored in woody capsules and is released following fire. The recruitment of this species in the absence of fire has not been studied, but light limitation is not likely to be an impediment to germination and survival in many areas at the treeline and above. Its frequent mixture with much older individuals of more fire-sensitive species also strongly suggests continuous regeneration (Kirkpatrick \& Balmer 1991).

The study site is situated in the Tasmanian Wilderness World Heritage Area, listed by UNESCO for the outstanding universal value of both its natural and cultural heritage, including its distinctive alpine ecosystems (UNESCO 2008). This study area is therefore of global relevance, in addition to providing important information at a regional scale and filling a gap in the Australian published literature on treeline change.
Our aim in the present study was to assess vegetation change at an alpine treeline on Mount Rufus, Tasmania, in the period 2006-2016, firstly by examining change in vegetation composition above the treeline, and secondly by assessing any change in the density, heights and diameters of the tree E. coccifera in the vegetation above the treeline. We also investigated climatic data recorded at the nearest weather station to determine whether there is any evidence for changes in summer temperatures that may explain observed patterns in vegetation at the treeline. We hypothesised that the vegetation above the treeline is becoming increasingly dominated by forest species, and that the tree species E. coccifera is increasing in size and abundance above the treeline.

\section{METHODS}

\section{Study area}

Mount Rufus lies towards the southern end of the Cradle Mountain - Lake St Clair National Park in central Tasmania (pl. 1). The surface geology is composed of Triassic sandstone of the Upper Parmeener Supergroup. Glacial action has had a strong influence on the topography of the region, with large glaciers having been present on the northern and eastern slopes of the mountain during the Last Glacial Maximum (19 ka BP; Colhoun et al. 1996).

The most recent fire on Mt Rufus occurred in 1965 (Styger \& Balmer 2009) and completely burned the eastern ridge of the mountain, including all except a few small patches in the study area (pl. 1). Large dead stems of E. coccifera, some taller than $20 \mathrm{~m}$, that were killed in the fire, can still be observed standing below the treeline.

The dominant tree species is E. coccifera, which forms an abrupt treeline on the upper slopes of the mountain (pl. 2). The occurrence of abrupt treelines in Tasmanian is unusual, with only a few other locations across the state displaying similar sharpness (Kirkpatrick 1982). Above the treeline, the vegetation opens up into alpine heath dominated by Epacris serpyllifolia R.Br., Orites acicularis (R.Br.) Roem. \& Schult., O. revoluta R.Br. and Boronia citriodora Gunn ex Hook.f., with the occasional isolated E. coccifera. Small long-unburned patches are dominated by gymnosperms, including Microcachrys tetragona (Hook.) Hook.f.

Monitoring at the site began in 2006 as part of the Alpine Treeline Ecotone Monitoring Program within the Tasmanian Wilderness World Heritage Area (Styger \& Balmer 2009) undertaken by the Tasmanian Department of Primary Industries, Parks, Water and Environment. The purpose of this program was to measure site specific ecosystem responses to climate change and to use this information to predict responses at different spatial and temporal scales (Styger \& Balmer 2009). 

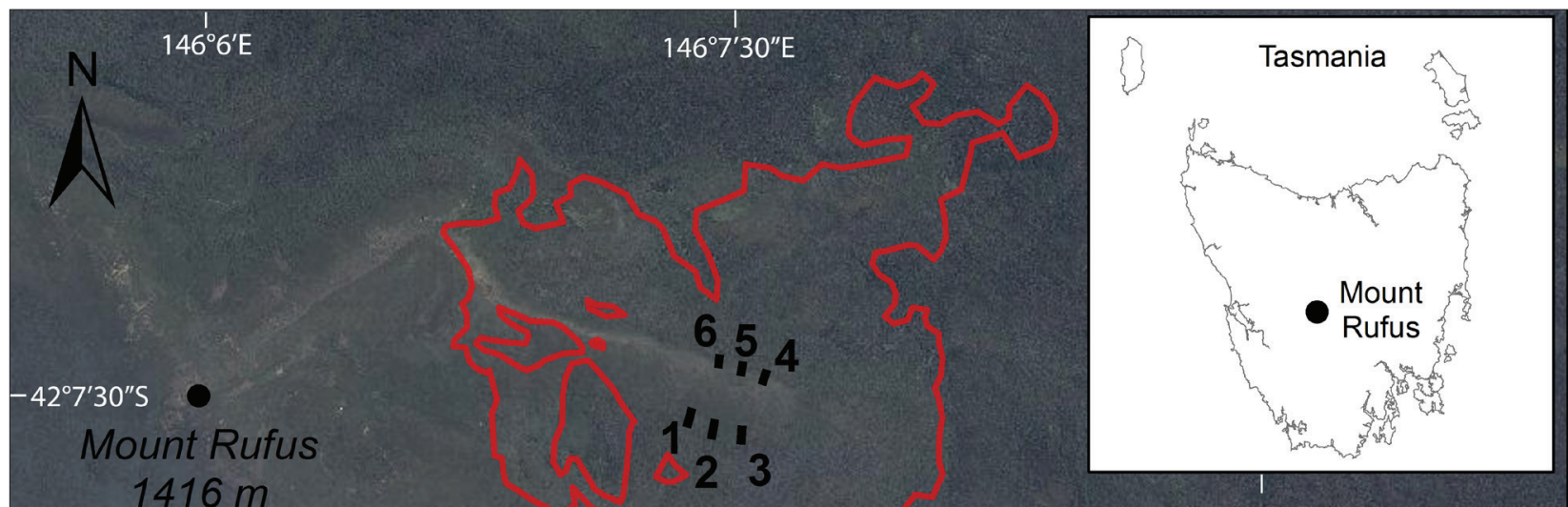

\section{Legend}

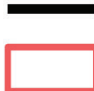

Transect location

1965 fire boundary

\begin{tabular}{|ccccc|}
\hline 0 & 0.425 & 0.85 & 1.7 & 2.55 \\
\hline & \multicolumn{4}{c|}{ Kilometres } \\
\hline
\end{tabular}

PLATE 1 - Location of transects at the study site on Mount Rufus, with approximate 1965 fire boundary mapped from a 1982 aerial photograph. Grid reference GCS WGS 1984 (Source: DPIPWE and Google Maps).

PLATE 2 - Comparison of an aerial photograph from 1953 and a satellite image from 2015 , showing the location of the treeline on Mount Rufus, Tasmania. Note the increase in the number of small Eucalyptus coccifera plants on the northern slope (A), and the expansion of a clump of $E$. coccifera on the southern slope (B) between images (Source: DPIPWE and Google Maps).

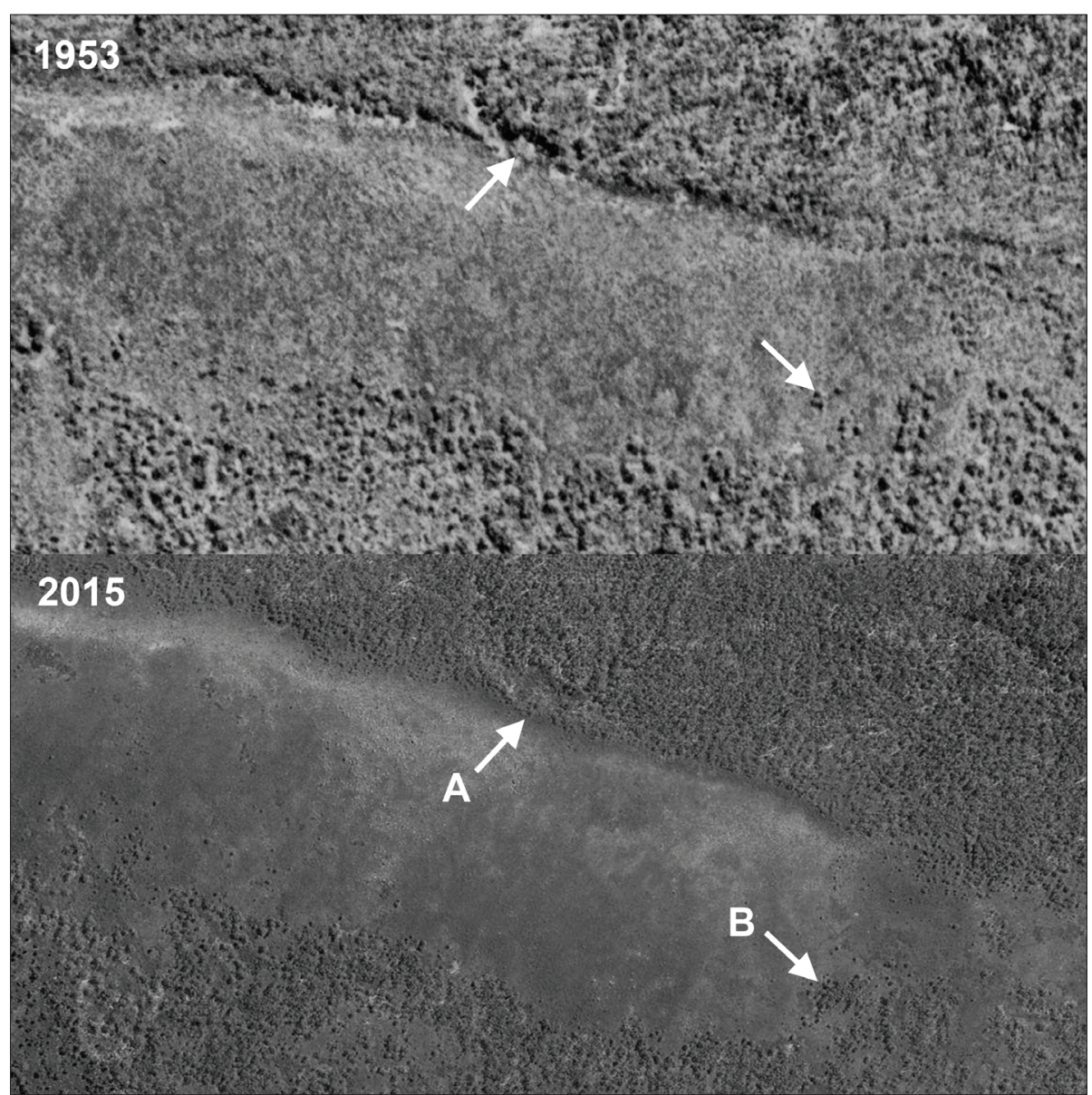




\section{Field data collection}

In 2006, three belt-transects were established on the northern aspect and three on the southern aspect of the Mt Rufus ridge (pl. 1). All six belt-transects included five $10 \times 10-\mathrm{m}$ plots above the treeline. Below the treeline the belt-transects varied in length with four comprising the full five $10 \times 10$-m plots, while two were reduced in length to $20 \mathrm{~m}$ and $40 \mathrm{~m}$ respectively because of the considerable sampling difficulty arising from the greater slope steepness and vegetation density. In 2016, only the upper and lower alpine quadrats in each belt-transect were resampled for species composition. Eucalyptus coccifera stems were resurveyed within all the alpine quadrats.

In each quadrat, vascular plant species cover was estimated as a percentage for each taxon. Those with less than $1 \%$ cover were entered as 0.5 . The maximum height for each shrub species $(\mathrm{cm})$ was also measured. The position, diameter at base and height, of all observed E. coccifera individuals in the alpine plots were recorded. Where possible, the $\mathrm{X}$ and $\mathrm{Y}$ co-ordinates were used to identify the individual E. coccifera trees recorded in 2006. This was not possible, however, where the tree was no longer present, or in plots where too many trees were present in close proximity to each other to accurately identify those originally recorded. All trees found that had not been listed previously were also recorded. If trees were found dead, or with dead wood present above living parts of the tree, this was also noted, and the maximum living height recorded.

Photo points were located at $10 \mathrm{~m}$ uphill, and at 10 $\mathrm{m}$ to the west, of the 0 and $50 \mathrm{~m}$ marks of each of the transects. The photographs were taken at each photo point focusing on a disc suspended $1.4 \mathrm{~m}$ above the permanent stake points (at 0 and $50 \mathrm{~m}$ on the transect line). Photographs were taken at each of the photographic monitoring points in both 2006 and 2016.

\section{Data analysis}

Non-metric multidimensional scaling ordination (NMDS) using the program DECODA (Minchin 1990) was used to ordinate the species cover data for the pool of quadrats at both dates. Uniform random coordinates were used for ten starting configurations in up to four dimensions, with a maximum number of 200 iterations. A solution scaling option of two half changes was selected. Rotational correlation analysis was used to find the best fit between the ordination axes derived from the NMDS and the variables aspect (north and south), date (2006 and 2016), and distance (quadrat number from one at highest elevation to the highest at lowest elevation, treeline between five and six), in three-dimensional space. The axes were shown to be respectively highly correlated with distance from treeline, aspect and date. One way analysis of variance was used to test for the effects that each of aspect, date and distance had on change in floristic composition as indicated by the axis scores. The paired t-test was used to determine the significance of changes in cover of the more abundant species between dates. The relationship between $E$. coccifera height and density change between 2006 and 2016 and change in the "alpineness" of the floristic composition as indicated by the scores on the axis related to distance was tested using linear regression analysis. Minitab 16 (Minitab Inc. 2010) was the primary software used for statistical analysis, unless stated otherwise.

The Kruskal-Wallis $\mathrm{H}$ test was used to test the significance of differences in tree height change, and tree density change, between 2006 and 2016, distance (quadrat number) and aspect (north- versus south-facing slopes). The differences between height classes $(<50 \mathrm{~cm}, 50-100 \mathrm{~cm}$ and $>100 \mathrm{~cm})$ for all trees that were re-identified in 2016 from the 2006 survey (hereafter referred to as paired trees) were tested for any significant change using the Kruskal-Wallis $\mathrm{H}$ test. The differences in E. coccifera height between 2006 and 2016 was also divided into a second set of height classes $(<100 \mathrm{~cm}$ and $>100 \mathrm{~cm})$, and linear regression used to determine any trend in height change within the two height classes between years. The effect of aspect on paired tree height change between 2006 and 2016 was tested using the Kruskal-Wallis $\mathrm{H}$ test. This test was repeated using only trees less than $100 \mathrm{~cm}$ in height.

The closest weather station is located at Lake St Clair (427'4"S, $146^{\circ} 10^{\prime} 38^{\prime \prime} \mathrm{E}, 742 \mathrm{~m}$ asl), with regular temperature and rainfall data being available for the years 1989 onwards. An environmental lapse rate of $0.75^{\circ} \mathrm{C}$ per $100 \mathrm{~m}$ change in elevation for maximum temperature, $0.5^{\circ} \mathrm{C}$ per $100 \mathrm{~m}$ for minimum temperature, and $0.63^{\circ} \mathrm{C}$ per $100 \mathrm{~m}$ for mean daily temperature (Nunez \& Colhoun 1986) was used to calculate approximate temperatures at the study site, situated at $\sim 1200 \mathrm{~m}$. Pearson's product moment correlation coefficient was used to determine the linear relationship between time and the daily mean, maximum, and minimum temperatures for the month of January, and total precipitation for the summer and winter months, for the years 1991 to 2015. Total annual precipitation was analysed using the same methods. Data were sourced from the Bureau of Meteorology Climate Data Online in 2016.

\section{RESULTS}

At the alpine treeline on Mt Rufus, the mean daily summer temperature (Dec-Feb) was calculated to be $8.9^{\circ} \mathrm{C}$. There is a marked seasonality in precipitation at Lake St Clair, with winter receiving a monthly mean of $201.8 \mathrm{~mm}$, while in summer the monthly mean is $104.9 \mathrm{~mm}$. The annual precipitation is $1856.7 \mathrm{~mm}$. The mean is likely to be much higher near the summit of Mt Rufus. Lake St Clair has experienced no systematic change in daily mean $(r=0.259$, $\mathrm{p}=0.211)$, maximum $(\mathrm{r}=0.271, \mathrm{p}=0.190)$, or minimum $(\mathrm{r}=0.105, \mathrm{p}=0.618)$ temperature, or precipitation $(\mathrm{r}=$ $-0.018, \mathrm{p}=0.934)$ for January for the 25 years between 1991 and 2015 (fig. 1). Annual precipitation ( $r=-0.269$, $\mathrm{p}=0.215$ ), and the seasonality of precipitation (summer: $\mathrm{r}=-0.113, \mathrm{p}=0.591$, winter: $\mathrm{r}=-0.204, \mathrm{p}=0.328$ ) also showed no trend. 


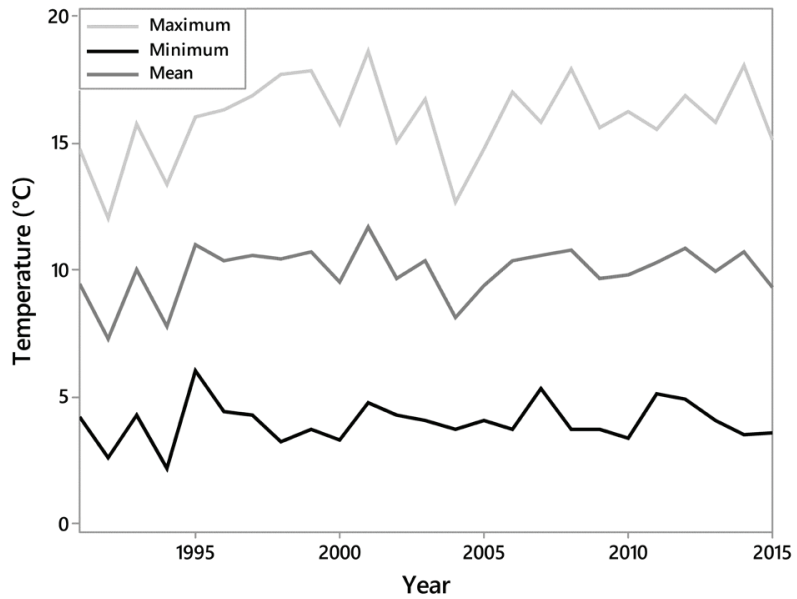

FIG. 1 - Mean daily maximum, minimum and mean temperatures for the month of January (between 1991 and 2015) at the study site on Mount Rufus ( 1200 m). Temperatures corrected for altitude from Lake St Clair weather station using an adiabatic lapse rate of $0.75^{\circ} \mathrm{C} / 100$ $\mathrm{m}$ for maximum, $0.5^{\circ} \mathrm{C} / 100 \mathrm{~m}$ for minimum, and $0.63^{\circ} \mathrm{C} / 100$ $\mathrm{m}$ for mean (Nunez \& Colhoun 1986) (Data from Bureau of Meteorology, accessed 2016).

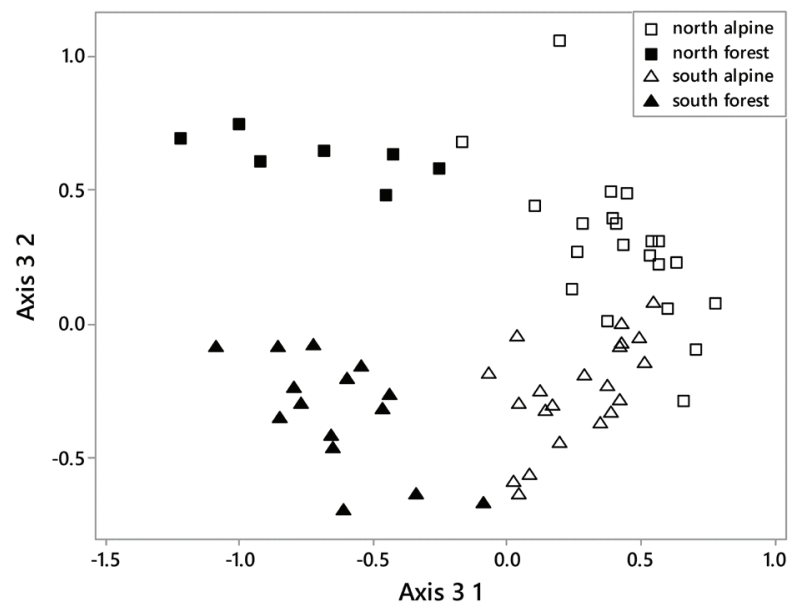

FIG. 3 - Difference in floristic composition between northand south-facing slopes. "Alpine" describes the vegetation characteristics of the upper quadrats while "forest" describes the lower quadrats. Axis 31 is related to "alpineness", with higher values suggesting a floristic composition more affiliated with the alpine vegetation of the upper quadrats, while a lower value suggests closer affiliation with the forest vegetation of the lower quadrats. Axis 32 is related to aspect, with higher values suggesting an affiliation with the vegetation of the north-facing slopes, and lower values the south-facing slopes.

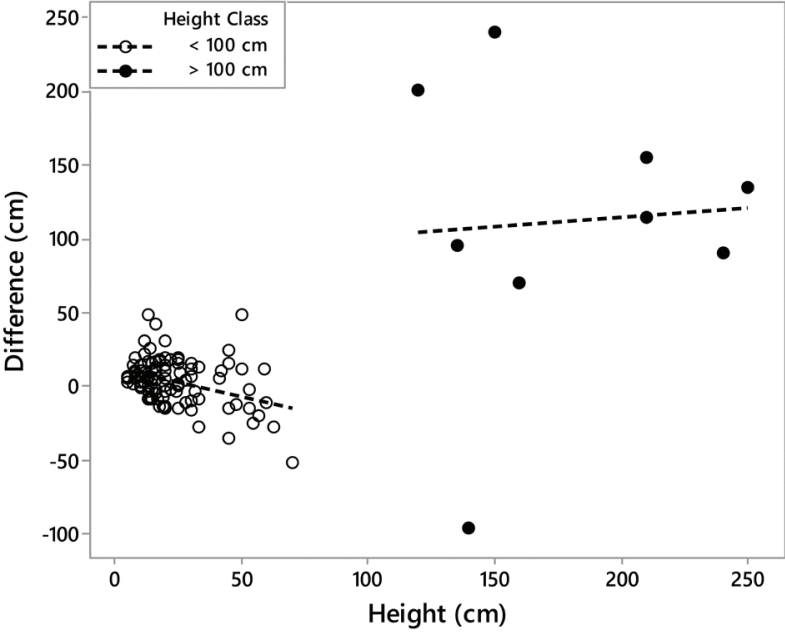

FIG. 2 - Difference in Eucalyptus coccifera height between 2006 and 2016 for paired trees related to height in 2006 (total = $111,<100 \mathrm{~cm}=102,>100 \mathrm{~cm}=9$ ), showing lines of best fit.

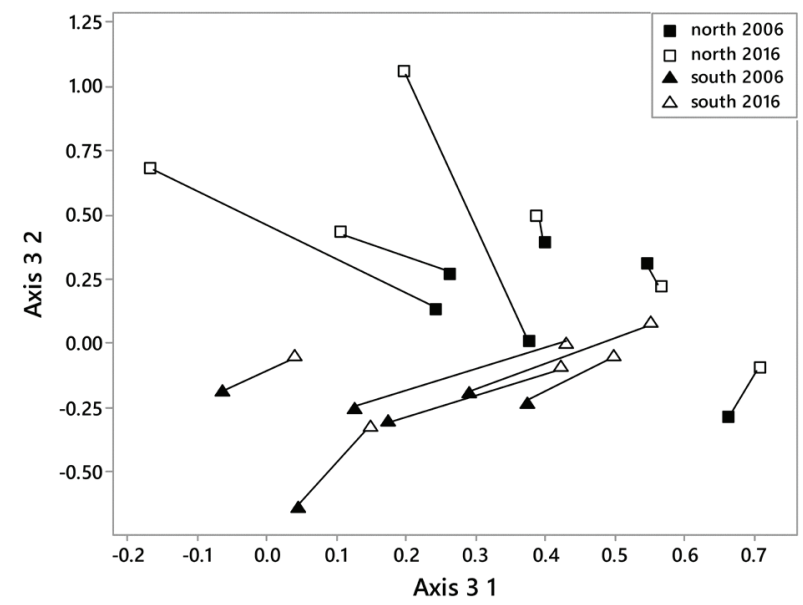

FIG. 4 - Direction of change for floristic composition for quadrats on north- and south-facing slopes between 2006 and 2016. Axis 31 is related to "alpineness", with higher values suggesting a floristic composition more affiliated with the alpine vegetation of the upper quadrats, and a lower value suggesting closer affiliation with the forest vegetation of the lower quadrats. Axis 32 is related to aspect, with higher values suggesting an affiliation with the vegetation of the north-facing slopes, and lower values the south-facing slopes. 
Individual E. coccifera plants were perceptible at higher altitudes on the north-facing slope in 2015 than in 1953 (pl. 3). On the south-facing slope more individuals were perceptible in 2015 than in 1953 in some E. coccifera clusters (pl. 2). However, none of the individual $E$. coccifera above the 1953 treeline had exceeded $3 \mathrm{~m}$ in height by 2016 .

Eucalyptus coccifera density decreased in the alpine quadrat furthest from the boundary (1) and in the quadrat second from the boundary (4), but increased in other quadrats (table 1 ). The median height of E. coccifera increased by $70 \%$, from $20 \mathrm{~cm}$ in 2006 to $34 \mathrm{~cm}$ in 2016 . E. coccifera heights in the quadrat closest to the boundary (5) were greater than those further away for $2006(n=$ 384, $H=26.8, d f=4, p<0.001)$ and $2016(n=584, H$ $=126.8, d f=4, p<0.001)$. In both 2006 and 2016 the median height was greater on the south-facing slope $(n$ $=26$, median $=50 \mathrm{~cm}$ ) than on the north-facing slope $(n=584$, median $=33 \mathrm{~cm})$. The number of $E$. coccifera increased for all height classes (table 2).

For all paired E. coccifera, those with 2006 heights greater than $100 \mathrm{~cm}$ showed the greatest increase in height, with a median difference of $115 \mathrm{~cm}$, while those in the less than $50 \mathrm{~cm}$ and $50-100 \mathrm{~cm}$ height classes increased by a median of $5.5 \mathrm{~cm}$ and decreased by 13 cm respectively ( $n=111, H=18.68, d f=2, p<0.001)$. Paired E. coccifera with a height greater than $100 \mathrm{~cm}$ in 2006 had no tendency in height difference between 2006 and 2016 with height $\left(r^{2}=0.4, d f=8, p=0.864\right)$, whereas the shorter individuals in 2006 had a negative relationship $\left(r^{2}=12.8, d f=101, p<0.001\right)$, with $58.8 \%$ of $E$. coccifera in this height class increasing in height, and 41.2\% decreasing in height (fig. 2).

Aspect had a significant effect on growth for all paired $E$. coccifera, with those on the north-facing slope increasing in height by a median of $4 \mathrm{~cm}$, compared to the median increase of $14.5 \mathrm{~cm}$ on the south-facing slope $(n=111$, $H=4.95, d f=1, p=0.026)$. However, this difference was strongly influenced by several tall $(>100 \mathrm{~cm})$ individuals on the south-facing slope. When considering only those trees less than $100 \mathrm{~cm}$, aspect had no significant effect on

TABLE 1 - Average density of Eucalyptus coccifera for each quadrat above the treeline between the years 2006 and 2016.

\begin{tabular}{lrccc}
\hline Quadrat & $\begin{array}{c}\text { Density } \\
2006 \\
\text { (trees/ha) }\end{array}$ & $\begin{array}{c}\text { Density } \\
2016 \\
\text { (trees/ha) }\end{array}$ & $\begin{array}{c}\text { Difference } \\
\text { (trees/ha) }\end{array}$ & $\begin{array}{c}\text { Percentage } \\
\text { change }\end{array}$ \\
\hline 1 & 433.3 & 400.0 & -33.3 & -7.7 \\
2 & 283.3 & 466.7 & 183.3 & 64.7 \\
3 & 800.0 & 800.0 & 0.0 & 0.0 \\
4 & 1683.3 & 1066.7 & -616.7 & -36.6 \\
5 & 3200.0 & 7000.0 & 3800.0 & 118.8 \\
\hline
\end{tabular}

E. coccifera growth $(n=111, H=0.09, d f=1, p=0.758)$.

There was no relationship between the change in floristic composition over time, represented by the "date" axis, with change in $E$. coccifera height $\left(R^{2}=1.2, d f=1, p=\right.$ $0.732)$ or density $\left(R^{2}=0.1, d f=1, p=0.926\right)$. The degree of floristic "alpineness" above the treeline (quadrats 1 to 5) differed from quadrats below the treeline (quadrats 6 +) $\left(R^{2}=85.1, d f=9, p<0.001\right)$. Aspect also had an influence on vegetation, with the north- and south-facing slopes displaying different assemblages of taxa $\left(R^{2}=44.58\right.$, $d f=1, p<0.001$, fig. 3). Ten species changed in cover between 2006 and 2016, with the strongest increasers being the alpine-dominant shrub, Orites acicularis, and E. coccifera, and the strongest decreasers being grass and herb species (table 3).

Floristic composition changed more on the north-facing slope than the south-facing slope (fig. 4). On the southfacing slope the quadrats became more alpine, while the quadrats on the north-facing slope largely became less alpine (fig. 4).

The repeat photographs show increases in alpine shrubs, particularly $O$. acicularis, and an increase in E. coccifera abundance near the treeline. Eucalyptus coccifera below the treeline increased both in height and density (pl. 3).

\section{DISCUSSION}

The climatic treeline at the study site on Mount Rufus, identified from aerial photographs and ground truthing, is approximately $1220 \mathrm{~m}$ on the north-facing slope, and $1210 \mathrm{~m}$ on the south-facing slope. Aspect-related differences in levels of insolation (Kirkpatrick \& Nunez 1980) make summer temperatures higher on north-facing slopes.

The increase in E. coccifera height and density between 2006 and 2016 was consistent with the increase in number of individuals of $E$. coccifera above the treeline evident between the 1953 and 2015 photographs, suggesting that a slow invasion has been taking place over the past 62 years, or that the 1965 fire created conditions suited to establishment of seedlings, although Green (2009) found

TABLE 2 - Change in number of Eucalyptus coccifera measured for each height class in 2006 and 2016.

\begin{tabular}{lrccc}
\hline Height class & $\begin{array}{c}\text { Number } \\
2006\end{array}$ & $\begin{array}{c}\text { Number } \\
2016\end{array}$ & Difference & $\begin{array}{c}\text { Percentage } \\
\text { change }\end{array}$ \\
\hline $0-50 \mathrm{~cm}$ & 350 & 435 & 85 & 24.3 \\
$50-100 \mathrm{~cm}$ & 22 & 122 & 100 & 454.5 \\
$>100 \mathrm{~cm}$ & 12 & 27 & 15 & 125 \\
Total & 384 & 584 & 200 & 52.1 \\
\hline
\end{tabular}




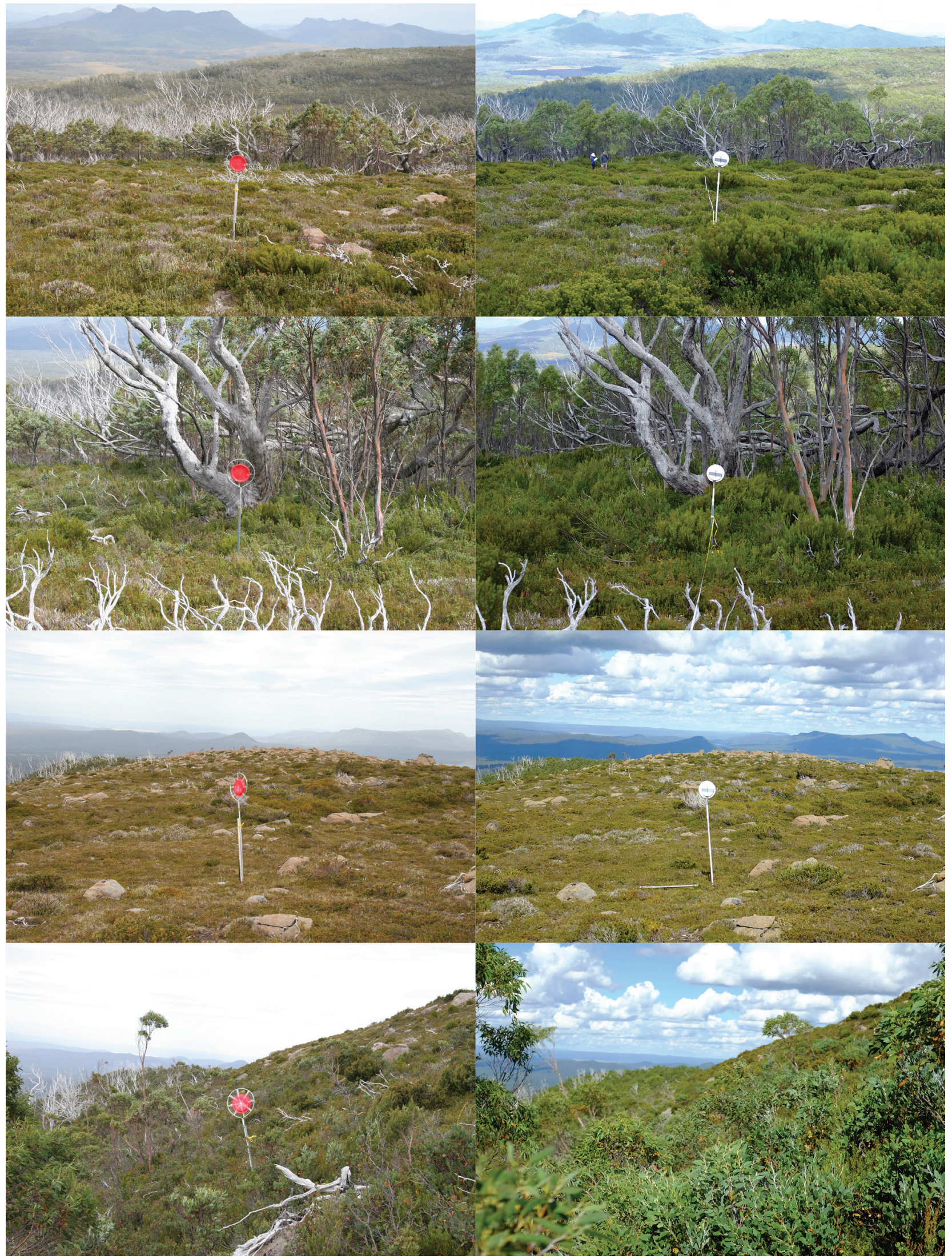

PLATE 3 - Photographs showing vegetation change between 2006 (left) and 2016 (right): from top, photopoint T3 0 (Transect 30 m) South, T3 50 South, T6 0 East, T6 50 East. 
TABLE 3 - Mean percentage cover of taxa that experienced a significant change between 2006 and 2016 in the twelve repeat quadrats.

\begin{tabular}{lcccc}
\hline Taxon & $\begin{array}{c}\text { Percentage Cover } \\
2006\end{array}$ & $\begin{array}{c}\text { Percentage Cover } \\
2016\end{array}$ & $\begin{array}{c}\text { Percentage } \\
\text { Change }\end{array}$ & $p$ \\
\hline Coprosma nitida $(\mathrm{sh})$ & 0.29 & 0.13 & -55.17 & $<0.05$ \\
Eucalyptus coccifera $(\mathrm{tr})$ & 1.54 & 4.58 & 197.40 & $<0.05$ \\
Gonocarpus montanus $(\mathrm{h})$ & 0.33 & 0.08 & -75.76 & $<0.01$ \\
Oreobolus acutifolius $(\mathrm{se})$ & 2.04 & 4.29 & 110.29 & $<0.05$ \\
Oreobolus pumilio $(\mathrm{se})$ & 0.37 & 0.04 & -89.19 & $<0.05$ \\
Orites acicularis $(\mathrm{sh})$ & 2.75 & 7.92 & 188.00 & $<0.01$ \\
Ozothamnus rodwayi $(\mathrm{sh})$ & 11.54 & 3.46 & -70.02 & $<0.01$ \\
Poa spp. (grass) & 9.42 & 1.21 & -87.15 & $<0.01$ \\
Richea sprengelioides $(\mathrm{sh})$ & 5.33 & 1.17 & -78.05 & $<0.01$ \\
Senecio leptocarpus $(\mathrm{h})$ & 0.79 & 0.08 & -89.87 & $<0.01$ \\
\hline
\end{tabular}

$\mathrm{h}=$ herb, se $=$ sedge, $\mathrm{sh}=$ shrub, $\operatorname{tr}=$ tree.

$p=$ probability from paired t-test.

no effect of fire on the establishment of eucalypts above the Snowy Mountains alpine treeline. Even though no change in climate has been observed at Lake St Clair in the past 25 years, there are no direct climatic data from Mount Rufus, leaving open the possibility of variable climatic change over the altitudinal gradient.

One possible explanation for the increase in tree height and density could be an increase in days of snow cover in the winter months. Snow cover protects underlying vegetation from freezing winter temperatures and abrasive winds (McVean 1958). Grose (1960) found that $E$. delegatensis RT Baker seedlings whose crowns protruded from the snow were susceptible to death, as they were exposed to the harsh freeze/thaw conditions at the surface of the snow, the "kill zone". Those seedlings that were small enough to be buried entirely below the snow were insulated from the harsher conditions at the surface of the snow. The different height changes for each height class observed at the study site are consistent with this observation. An increase in depth and/or duration of snow at the study site could assist in protecting small $E$. coccifera seedlings in the colder months. The past three decades have seen a small increase in the number of days that experience snow at Mount Rufus (Kirkpatrick pers. comm. 2016), which is likely to have been associated with greater snow depths and duration of snow lie on the ground, although these more important predictors of tree survival have not been measured. The effect of this snow cover protection would be most pronounced on the north-facing slope, where the greatest amount of snow accumulates in a snow patch (pl. 4), which is the same area in which the greatest increase in E. coccifera height and density were observed.

Our data suggest that, once trees exceeded $100 \mathrm{~cm}$ height they were able to overcome obstacles to growth. The negative relationship between growth and 2006 size evident for trees below $100 \mathrm{~cm}$ in height in 2006 could possibly indicate that some cycle of regeneration is taking place, with trees below a certain height threshold dying back then resprouting from lignotubers. Once these survivors have reached $100 \mathrm{~cm}$, the putative freeze/thaw that kills off the medium-sized E. coccifera is absent, and they continue to grow. The high number of large, gnarled lignotubers supporting small $E$. coccifera observed at the site support this hypothesis, as the age of the lignotuber is clearly much greater than that of the regrowth it supports.

The differences in vegetation composition change between the north- and south-facing slopes may relate to the greater dryness and instability on the steep, wellinsolated north-facing slope, where snow accumulates to greater depth in winter than on the gentler south-facing slope. E. coccifera is better suited to well-drained rather than waterlogged conditions (Gilfedder 1988, Kirkpatrick \& Gibson 1998). Although there was a greater increase in tree density on the north-facing slope, in most quadrats the increase was not sufficient to influence vegetation composition as shown by the lack of relationship between the variables related to E. coccifera and those related to species composition.

On the southern slope, the increase in "alpine" vegetation may be related to succession processes, with vegetation still recovering from fire. These succession processes may be more pronounced on the south-facing aspect than the north due to the less regular disturbance compared to that experienced by the north. The obligate seed regenerator, Orites acicularis (R.Br.) Roem. \& Schult., has greater cover on unburned sites than in burned sites elsewhere in Tasmania (Kirkpatrick et al. 2010). It appears to be slowly recovering since the area was last burnt in 1965 at the same rate as observed on Mt Wellington (Kirkpatrick et al. 2002b). Conversely, the decreasers at Mt Rufus have all been found in higher numbers in burned than unburned sites in alpine Tasmania (Kirkpatrick et al. 2010).

In terms of future vegetation composition, the impacts of climate change are relevant, as lightning fire has become more frequent in western Tasmania (Marsden-Smedley 2009). If fires were to become more frequent at Mt Rufus, major vegetation change could be anticipated. 


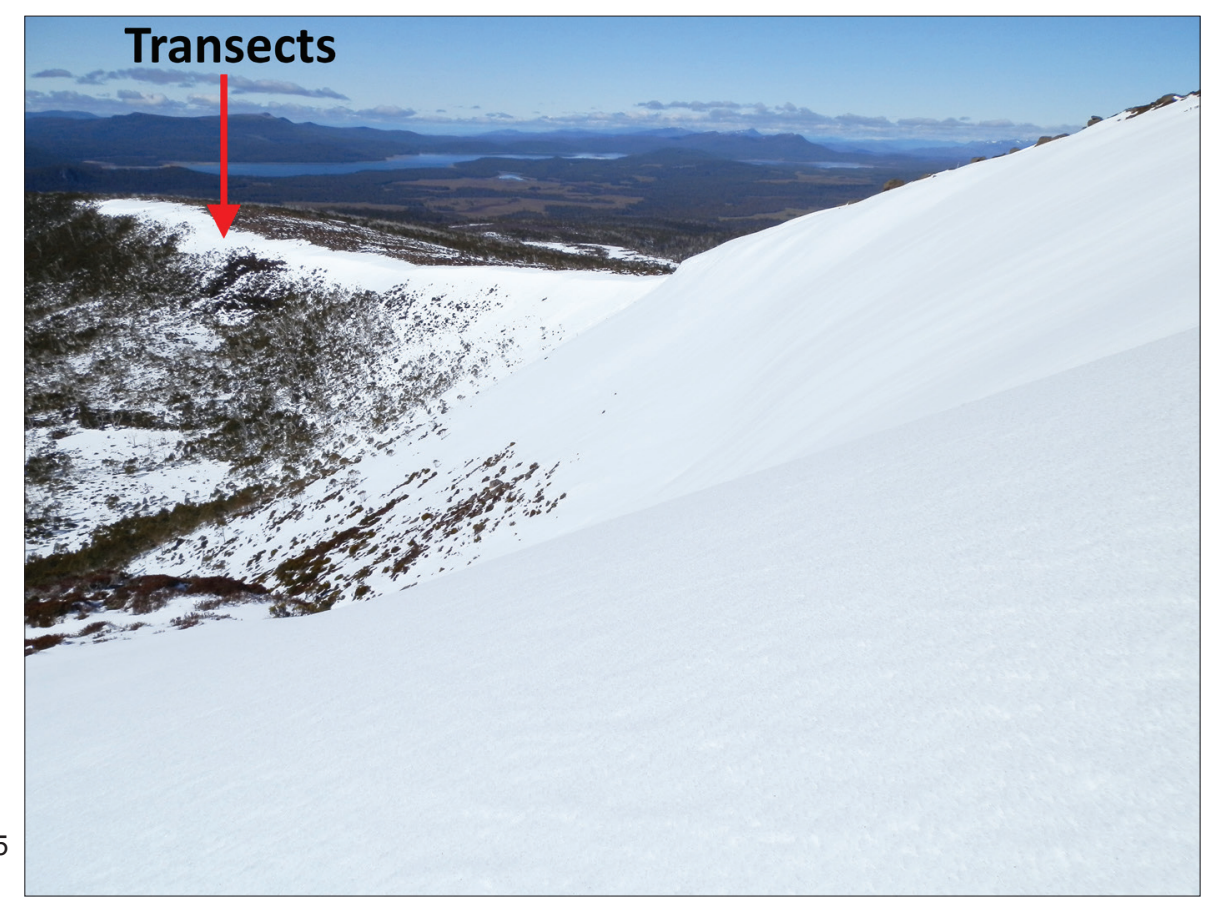

PLATE 4 - Snow accumulation on the eastern and northern slopes of Mt Rufus, Tasmania, looking east towards the transect locations.

Photograph taken 1 September 2015 (Source: B. Annandale).

The lack of advance of the E. coccifera treeline in the past 10 years, or during the past six decades, is consistent with the persistence of abrupt treelines noted globally, even where climate has changed, by Harsch et al. (2009). This phenomenon has also been observed by Green (2009) in the Snowy Mountains. However, tree height and density has increased in the past 10 years, although this has not yet brought about a shift in treeline location, as all trees remain less than $3 \mathrm{~m}$ in height.

It is difficult to determine whether the increase in height and density is a result of climatic change or a symptom of recovery from the 1965 fire. Floristic composition has changed differently depending on aspect, with the vegetation situated on the south-facing slope becoming more dominated by alpine shrubs, and that on the north-facing slope becoming more closely similar to the vegetation below the treeline. As individuals of $E$. coccifera increase in height they may transgress the $3 \mathrm{~m}$ barrier, shifting the treeline.

We therefore conclude that there have been changes in the vegetation above the treeline, including some thickening and height growth of E. coccifera in its shrub stage, that there is no strong evidence for climate change, and that the hypothesis that forest species gained more dominance above the treeline is incorrect for south-facing slopes, but correct for north-facing slopes.

\section{ACKNOWLEDGEMENTS}

This monitoring project has been funded by both ES Link and the Australian Government and Tasmanian State Government through the World Heritage Area partnership program. This long-term monitoring project and the associated vegetation data are maintained within the Natural Values Conservation Branch, Department of
Primary Industries, Parks and Environment, which also provided logistical support for the 2016 survey work. Nick Lewis of ES Link established the transects on Mount Rufus. The initial vegetation data were collected with assistance from Cassie Strain, Jennie Whinam, Felicity Hargraves and Angela Jackson.

\section{REFERENCES}

Bridle, K.L., Kirkpatrick, J.B., Cullen, P. \& Shepherd, R.R. 2001: Recovery in alpine heath and grassland following burning and grazing, eastern Central Plateau, Tasmania. Arctic, Antarctic and Alpine Research 33: 348-356.

Camac, J.S., Williams, R.J., Wahren, C.H., Jarrad, F., Hoffmann, A.A. \& Vesk, P.A. 2015: Modeling rates of life form cover change in burned and unburned alpine heathland subject to experimental warming. Oecologia 178: 615-628.

Colhoun, E.A., Hannan, D. \& Kiernan, K. 1996: Late Wisconsin glaciation of Tasmania. Papers and Proceedings of the Royal Society of Tasmania 130: 33-45.

Costin, A.B., Gray, M., Totterdell, C.J. \& Wimbush, D.J. 1979: Kosciusko Alpine Flora, CSIRO/ Collins, Sydney: 408 pp.

Gibson, N. \& Kirkpatrick, J.B. 1992: Dynamics of a Tasmanian cushion heath community. Journal of Vegetation Science 3: 647-654.

Gilfedder, L. 1988: Factors influencing the maintenance of an inverted Eucalyptus coccifera tree-line on the Mt Wellington Plateau, Tasmania. Australian Journal of Ecology 13: 495-503.

Green, K. 2009: Causes of stability in the alpine treeline in the Snowy Mountains of Australia - a natural experiment. Australian Journal of Botany 57: 171-179.

Green, K. \& Pickering, C.M. 2009: The decline of snowpatches in the Snowy Mountains of Australia: importance of climate warming, variable snow and wind, Arctic, Antarctic, and Alpine Research 41: 212-218.

Green, K. \& Stein, J.A. 2015: Modeling the thermal zones and biodiversity on the high mountains of Meganesia: the importance of local differences. Arctic, Antarctic, and Alpine Research 47: 671-680. 
Greenwood, S. \& Jump, A.S. 2014: Consequences of treeline shifts for the diversity and function of high altitude ecosystems, Arctic, Antarctic, and Alpine Research 46: 829-840.

Grose, R.J. 1960: The silviculture of Eucalyptus delegatensis R.T. Baker. Unpublished PhD thesis, University of Melbourne, Melbourne.

Hagedorn, F., Shiyatov, S.G., Mazepa, V.S., Devi, N.M., Grigor'ev, A.A., Bartysh, A.A., Fomin, V.V., Kapralov, D. S., Terent'ev, M., Bugman, H. \& Rigling, A. 2014: Treeline advances along the Urals mountain range-driven by improved winter conditions? Global Change Biology 20: 3530-3543.

Harsch, M.A, Hulme, P.E, McGlone, M.S. \& Duncan, R.P. 2009: Are treelines advancing? A global meta-analysis of treeline response to climate warming. Ecology Letters 12: $1040-1049$.

Kirkpatrick, J.B. 1982: Phytogeographical analysis of Tasmanian alpine floras. Journal of Biogeography 9: 255-271.

Kirkpatrick, J.B. 1983: Treeless plant communities of the Tasmanian high country. Proceedings of the Ecological Society of Australia 12: 61-77.

Kirkpatrick, J.B. \& Balmer, J. 1991: The vegetation and flora of the Cradle Mountain-Pencil Pine area, Tasmania. In Smith, S.J. (ed.): Aspects of Tasmanian botany. Royal Society of Tasmania, Hobart: 119-148.

Kirkpatrick, J.B. \& Bridle, K.L. 2013: Natural and cultural histories of fire differ between Tasmanian and mainland Australian alpine vegetation, Australian Journal of Botany 61: 465-474.

Kirkpatrick, J.B. \& Bridle, K.L. 2016: Grazing and the absence of fire promote the dominance of an unpalatable shrub in a patch mosaic cyclic successional system. Australian Journal of Botany 64: 45-50.

Kirkpatrick, J.B., Bridle, K.L. \& Dickinson, K.J.M. 2010: Decades-scale vegetation change in burned and unburned alpine coniferous heath. Australian Journal of Botany 58: 453-462.

Kirkpatrick, J.B., Bridle, K. \& Lynch, A.J.J. 2002a: Changes in vegetation and landforms at Hill One, Tasmania. Australian Journal of Botany 50: 753-759.

Kirkpatrick, J.B., Bridle, K.L. \& Wild, A.S. 2002b: Succession after fire in alpine vegetation on Mount Wellington, Tasmania. Australian Journal of Botany 50: 145-154.

Kirkpatrick, J.B. \& Dickinson, K.J.M. 1984: The impact of fire on Tasmanian alpine vegetation and soils. Australian Journal of Botany 32: 613-629.

Kirkpatrick, J.B. \& Gibson, N. 1998: Responses to waterlogging and frost related to the topographic sequences of eucalypt species at three sites in central Tasmania, Papers and Proceedings of the Royal Society of Tasmania 132: 31-34.

Kirkpatrick, J.B. and Nunez, M. 1980: Vegetation-radiation relationships in mountainous terrain: eucalypt-dominated vegetation in the Risdon Hills, Tasmania. Journal of Biogeography 7: 197-208.

Marsden-Smedley, J.B. 2009: Planned burning in Tasmania: operational guidelines and review of current knowledge. Fire Management Section, Parks and Wildlife Service, Department of Primary Industries, Parks, Water and the Environment, Hobart, Tasmania: 100 pp.

McVean, D.N. 1958: Snow cover and vegetation in the Scottish Highlands, Weather 13: 197-200.

Minchin, P. 1990: DECODA - Database for ecological community data, version 2.02. Research School of Pacific Studies, Australian National University, Canberra.

Minitab Inc. 2010: Minitab Users Guide Release 16. Minitab Inc., USA.

Nunez, N. \& Colhoun, E.A. 1986: A note on air temperature lapse rates on Mount Wellington, Tasmania. Papers and Proceedings of the Royal Society of Tasmania 120: 11-15.
Parry, J., Kirkpatrick, J.B. \& Marsden-Smedley, J. 2016: Explaining the distribution, structure and species composition of snow patch vegetation in Tasmania, Australia. Australian Journal of Botany 64: 484-491.

Paulsen, J. \& Körner, C. 2014: A climate-based model to predict potential treeline position around the globe. Alpine Botany 124: $1-12$.

Pickering, C., Hill, W. \& Green, K. 2008: Vascular plant diversity and climate change in the alpine zone of the Snowy Mountains, Australia. Biodiversity Conservation 17: 1627-1644.

Pyrke, A.F. \& Kirkpatrick, J.B. 1994: Growth rate and basal area response curves of four Eucalyptus species on Mt. Wellington, Tasmania. Journal of Vegetation Science 5: 13-24.

Settele, J., Scholes, R., Betts, R., Bunn, S., Leadley, P., Nepstad, D., Overpeck, J.T. \& Taboada, M.A. 2014: Terrestrial and inland water systems. In Field, C.B., Barros,V.R., Dokken, D.J., Mach, K.J., Mastrandrea, M.D., Bilir, T.E., Chatterjee, K.L., Ebi, Y.O. Estrada, R.C., Genova, B., Girma, E.S., Kissel, A.N., Levy, S., MacCracken, P.R., Mastrandrea, M.D. \& White, L.L. (eds): Climate Change 2014: Impacts, Adaptation, and Vulnerability. Part A: Global and Sectoral Aspects. Contribution of Working Group II to the Fifth Assessment Report of the Intergovernmental Panel on Climate Change. Cambridge University Press, Cambridge: 271-359.

Shaw, M.J., Potts, B.M., \& Reid, J.B. 1984. Variation within and between Eucalyptus nitida Hook. F. and E. coccifera Hook. F. Australian Journal of Botany 32: 641-654.

Styger, J. \& Balmer, J. 2009: Alpine treeline ecotone monitoring program within the Tasmanian Wilderness World Heritage Area. Nature Conservation Report 2009/4, Department of Primary Industries, Parks, Water and Environment, Hobart.

UNESCO 2008. Operation guidelines for the implementation of the World Heritage Convention. World Heritage Centre. <http://whc.unesco.org/archive/opguide08-en. pdf> (accessed 20 February 2016).

Venn, S.E., Green, K., Pickering, C.M. \& Morgan J.W. 2011: Using plant functional traits to explain community composition across a strong environmental filter in Australian alpine snowpatches. Plant Ecology 212: 1491-9.

Venn, S.E., Pickering, C.M. \& Green, K. 2012: Short-term variation in species richness across an altitudinal gradient of alpine summits. Biodiversity and Conservation 21: $3157-3186$.

Venn, S., Pickering, C. \& Green, K. 2014: Spatial and temporal functional changes in alpine summit vegetation are driven by increases in shrubs and graminoids, Annals of Botany Plants 6 (plu008): 1-15. <http://aobpla.oxfordjournals. org/content/6/plu008.full.pdf+html> (accessed 6 March 2016).

Williams, K.J., \& Potts, B.M. 1996 The natural distribution of Eucalyptus species in Tasmania. TASFORESTS 8: 39-165.

Williams, R.J., Wahren, C.-H., Stott, K.A.J., Camac, J.S., White, M., Burns, E., Harris, S., Nash, M., Morgan, J.W., Venn, S., Papst, W.A. \& Hoffmann, A.A. 2015: An International Union for the Conservation of Nature Red List ecosystems risk assessment for alpine snow patch herbfields, South-Eastern Australia. Austral Ecology 40: 433-443.

Williams, R.J., Wahren, C.-H., Tolsma, A.D., Sanecki, G.M., Papst, W.A., Myers, B.A., McDougall, K.L., Heinze, D.A. \& Green, K. 2008: Large fires in Australian alpine landscapes: their part in the historical fire regime and their impacts on alpine biodiversity. International Journal of Wildland Fire 17: 793-808.

(Accepted 6 September 2016) 